\title{
熱酸化フライ油のラット肝㵴脂質過酸化に 及ぼす影響について
}

(昭和 55 年 8 月 13 日受理)

井崎や元子*滕原光 雄:

\section{The Influence of Thermally Oxidized Frying Oil on Lipid Peroxidation in Rat Liver}

\author{
Yaeko IZAKI and Mitsuo FUJIwara
}

(Kyoto City Institute of Public Health: 1-2, Mibu Higashitakada-cho, Nakagyo-ku, Kyoto)

The effect of feeding rats with thermally oxidized rape seed oils (3 levels of deterioration; obtained from manufacturers of fried fish paste) on the lipid peroxidation in the rat liver was investigated. Rats were fed ad libitum for 42 days with diet which contained $20 \%$ sample oil.

Regardless of the control tocopherol level, groups fed thermally oxidized frying oil showed increased relative liver weight, TBA-positive substances and GSH content, in proportion to the level of deterioration of the oil, compared with the fresh oil-fed group.

These results suggest that some substances present in thermally oxidized oils act as radical generators in vivo.

(Received August 13, 1980)

Key words: 熱酸化フライ油 thermally oxidized frying oil; 脂質過酸化ラット肝蔵 lipid peroxidation in rat liver; トコフェロールレベル tocopherol level; 比肝重量 relative liver weight; TBA 反応陽性物質量 TBA positive substance content; グルタチオン量 glutathione content; グルタチオンパーオキシダーゼ活性 glutathione peroxidase activity; ラジカル生成 物質 radical generator; ラット rat

\section{緒言}

近年，生体内過酸化脂質が老化や各種疾病の発生要因 として重視されて来ており，これに関連する研究 ${ }^{1) ~ 3) ~}$ 活発化している．生体内過酸化脂質は，生体内不飽和脂 質がなんらかの radical generator の作用を受けて生成 するが，ビタミン E などの radical scavenger やグル タチオンパーオキシダーゼ系で代謝処理される，この生 成系と処理系にアンバランスを来たすと，過酸化脂質に 由来する疾病が生じると考えられている.

内山ら ${ }^{4)}$ は, 油脂の劣化に伴って生成するカルボニル 化合物のらち，12-ケトオレイン酸には不飽和脂質に対 する酸化促進作用（pro-oxidant 作用）があり，これが 体内に吸収された場合, 生体内不飽和脂質の過酸化に関
与する可能性があると指摘している。 また，Wantland $ら^{5)}$ により熱酸化油中に各種長鎖ケト不飽和脂肪酸が生 成することが報告されている．これらは，熱酸化油摂取 による生体内脂質過酸化促進を示唆するものとして注目 すべき報告である。

熱酸化油の一般的な 毒性に関しては, Nolen ら ${ }^{6)}$, Mankel ${ }^{7)}$, Poling $5^{8)}$, 浦上*2, Waltking $5^{9)}$ の文献 に総説的に紹介されており，それらによれば，有害説と 無害説の二つの立場があることがわかる. 一方は，実験 室的にか酷な条件で熱酸化させた油脂には生体に有害な 物質が生成し，これを真空蒸留法および尿素付加法 ${ }^{10)}$,

*2 浦上智子：照射食品を他山の石として食用油脂の安 全性（使用法）を考える。（日本油化学協会 関西 支部，第54回製油研究部会 資料. 1974. 3.) 
Table 1. The Quality of Sample Oils

\begin{tabular}{|c|c|c|c|c|c|c|c|c|}
\hline \multirow{2}{*}{ Sample oils } & \multicolumn{8}{|c|}{ Indices } \\
\hline & $\underset{(\%)}{\text { ox. FA }}$ & $\begin{array}{c}\mathrm{CoV} \\
(\mathrm{meq} / \mathrm{kg})\end{array}$ & $\mathrm{AV}$ & $\begin{array}{c}\mathrm{POV} \\
(\mathrm{meq} / \mathrm{kg})\end{array}$ & $\underset{(\%)}{\text { G. D. fr }}$ & IV & $\mathrm{P} / \mathrm{Ap}$ & $\begin{array}{c}\text { Toc } \\
(\mu \mathrm{g} / \mathrm{g})\end{array}$ \\
\hline $\begin{array}{l}\text { Fresh rape } \\
\text { seed oil (FI) }\end{array}$ & 0 & 9.0 & 0.03 & 0.9 & 0 & 123.9 & 0.31 & $\begin{array}{lr}\alpha, & 136.5 \\
\gamma, & 504.5 \\
\delta, & 41.2\end{array}$ \\
\hline $\begin{array}{l}\text { Toc-removed } \\
\text { fresh rape } \\
\text { seed oil (FII) }\end{array}$ & 0 & 3.5 & 0.03 & 1.7 & 0 & 123.9 & 0.74 & 0 \\
\hline $\begin{array}{l}\text { Thermally } \\
\text { oxidized rape } \\
\text { seed oil (A) }\end{array}$ & 0.95 & 67.2 & 2.81 & 14.4 & 0.99 & 113.6 & 7.15 & 0 \\
\hline$" \quad(\mathrm{~B})$ & 3.56 & 127.8 & 3.70 & 10.3 & 1.69 & 107.2 & 12.3 & 0 \\
\hline$" \quad(\mathrm{C})$ & 7.72 & 157.9 & 12.56 & 6.9 & 4.06 & 106.0 & 16.5 & 0 \\
\hline
\end{tabular}

ox. FA, oxidized fatty acid; Cov, carbonyl value; AV, acid value; POV, peroxide value; G. D. fr, glyceride dimer fraction; IV, iodine value; P/Ap, polar/apolar trigriceride ratio by TLC (at $230 \mathrm{~nm}$ ); Toc, tocopherols content.

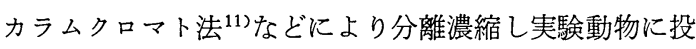
与すると, 胸腺の退縮, 肝壊死, 下痢, 死亡などの急性 毒性を示したとする報告である．これに対して，日常的 に使われる油脂の加熱条件では，なんらの健康阻害も示 さなかったとする見解( ${ }^{(2)}, 8$, 12) 女多く報告されている.

著者らは，先に揚物調理業者を対象に，使用フライ油 の品質実態調査を西ドイツ食品法の基準值 [石油エーテ ル不溶性酸化脂肪酸 (ox. FA) $0.7 \%$ 以下, 酸価 (AV) 2.5 以下, 発煙点 $170^{\circ}$ 以上] 適用して実施したが，一 部には ox. FA が基準值の約 10 倍に及ぶなど, 劣化の 著しいフライ油が使用されている事実を認めその結果を 報告13).14)した．乙かしながら，西ドイッにおいても ox. FA $0.7 \%$ を基準值として設定するに際しては，酸化脂 肪酸の毒性の程度から直接割り出されたものではなく, むしろ臭味，外観などの品質面から決定されたようであ る ${ }^{15)}$. そこで, 著者らは, 通常の温度で使用され，かつ ox. FA が $0.7 \%$ 以上である 3 種の熱酸化油を，さつま 揚げ製造所より入手し，ラットに投与し生体内脂質過酸 化に及ぼす影響を検討したので報告する。

\section{実験方法}

\section{1. 供 試 油}

1.1 熱酸化油および 対照新鮮油：さつま揚げ製造所 より連続使用中の熱酸化油（A，B および C) を入手し た.いずれもなたね白絞油で, 調理温度は $180^{\circ}$, 新油添 加率は $\mathrm{A}$ および C では $1.1 \% / \mathrm{h}, \mathrm{B}$ では $2.0 \% / \mathrm{h}$ であ った．対照新鮮油（FI）として，昭和産業製なたね白絞
Table 2. Composition of Diet

\begin{tabular}{lr}
\hline Basal diet $^{\text {a) }}$ & \\
Corn starch & $32.3 \%$ \\
Milk casein & $21.3 \%$ \\
Alpha starch & $8.5 \%$ \\
Cellulose powder & $6.8 \%$ \\
Granule sugar & $4.3 \%$ \\
Vitamins $^{\text {b) }}$ & $1.7 \%$ \\
Minerals $^{\text {c) }}$ & $5.1 \%$ \\
\hline Sample oil & $20.0 \%$ \\
\hline
\end{tabular}

a) Basal diet: linole salad oil eliminated from Oriental refined diet (combination B), purchased from Oriental Yeast Co. Ltd. (Tokyo)

b) Vitamins (in $100 \mathrm{~g}$ diet): V.A, $850 \mathrm{IU} ; \mathrm{V} . \mathrm{D}_{3}$, $170 \mathrm{IU} ; \mathrm{V} . \mathrm{B}_{1}, 2.0 \mathrm{mg} ; \mathrm{V} . \mathrm{B}_{2}, 6.8 \mathrm{mg} ; \mathrm{V} . \mathrm{B}_{6}$, $1.4 \mathrm{mg}$; V.B ${ }_{12}, 8 \mu \mathrm{g}$; V.C, $51 \mathrm{mg}$; V.E, $8.5 \mathrm{mg}$; V.K, $8.8 \mathrm{mg}$; Biotin, $0.03 \mathrm{mg}$; Folic acid, $0.34 \mathrm{mg}$; Ca-pantothenate, $8.5 \mathrm{mg}$; p-Amino benzoic acid, $8.5 \mathrm{mg}$; Niacin, $10.2 \mathrm{mg}$; Inositol, $10.2 \mathrm{mg}$; Cholin-Cl, $340 \mathrm{mg}$

c) Minerals (in $100 \mathrm{~g}$ diet): $\mathrm{K}, 377.2 \mathrm{mg} ; \mathrm{P}$, $536.0 \mathrm{mg}$; $\mathrm{Ca}, 405.1 \mathrm{mg}$; $\mathrm{Na}, 185.0 \mathrm{mg}$; $\mathrm{Mg}$, $51.0 \mathrm{mg} ; \mathrm{Fe}, 24.3 \mathrm{mg}$; $\mathrm{Zn}, 2.9 \mathrm{mg}$ Mn, 1.4 $\mathrm{mg}$; $\mathrm{Cu}, 0.39 \mathrm{mg} ; \mathrm{I}, 0.39 \mathrm{mg}$ 
Table 3. GSH-px Assay System

Assay mixture

Assay mixture $3 \mathrm{ml}$, containing

\begin{tabular}{l|c} 
& containing \\
\hline $0.2 \mathrm{ml}$ of $75 \mathrm{mmole} / \mathrm{L}$ GSHa) & $15 \mu \mathrm{mole}$ \\
$0.5 \mathrm{ml}$ of $1.2 \mathrm{mmole} / \mathrm{L}$ NADPH-4Na $\left.{ }^{\mathrm{a}}\right)$ & $0.6 \mu \mathrm{mole}$ \\
$0.1 \mathrm{ml}$ of $30 \mathrm{mmole} / \mathrm{L}$ EDTA-2Na & $3 \mu \mathrm{mole}$ \\
$0.01 \mathrm{ml}$ of 100 units/0.5 ml GSSG-reductase $\left.{ }^{\mathrm{a}}\right)$ & $2 \mu$ units \\
$1.59 \mathrm{ml}$ of $75 \mathrm{mmole} / \mathrm{L}$ Potassium phosphate buffer $\left.(\mathrm{pH} 7.0)^{\mathrm{a}}\right)$ & $119 \mu \mathrm{mole}$ \\
\hline $0.5 \mathrm{ml}$ of $100,000 \mathrm{~g}$-supernatant $(10 \sim 100$ fold dilution $)$ & \\
\hline $0.1 \mathrm{ml}$ of $10 \mathrm{mmole} / \mathrm{L}$ tert -butyl hydroperoxide & $1 \mu \mathrm{mole}$
\end{tabular}

Total volume is $3 \mathrm{ml}$ in silica cuvette.

The conversion of NADPH to NADP was followed by continuous recording of the change in absorbance of the system at $340 \mathrm{~nm}$ between 2 and 4 minutes after initiation of the reaction, employing a cuvette with a $1 \mathrm{~cm}$ light path

a) Premixed just before use into large fresh pools allowed more expeditious assays of multiple samples.

油を用いた。供試油は，それぞれ $20 \mathrm{~L}$ 容ガラス製試薬 ビンに入れ，ヘッドスペースを窒素ガスで置換し低温室 (5゚) に保存した.

1.2 脱トコフェロール新鮮油 ${ }^{16)}$ : カラムクロマト用 中性アルミナ (Woelm, 活性度 I), $1 \mathrm{~kg}$ を $110^{\circ}, 3$ 時 間乾燥後, $5 \mathrm{~cm} \times 1 \mathrm{~m}$ のガラス管に充填（ドライカラ ム）しこれに新鮮なたね油 $1 \mathrm{~kg}$ を常温, 減圧下で吸 引ろ過することによって脱トコフェロール新鮮油（FII） を調製した。

1.3 各供試油の品算： ox. FA その他各指標の測定 は，前報 ${ }^{133,14)}$ と同一方法で行った. ただし，TLCによ

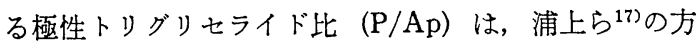
法によった。 また，供試油中の各トコフェロール(Toc) 同族体の分離定量は，GC による阿部ら ${ }^{18)}$ の方法で行っ た. Table 1 に供試油の品質および Toc 含量を示す.

\section{2. 動物実験}

実験 I では，Toc レベルをコントロールせずに各供 試油を無脂肪基礎飼料に加えて，20\% 含油飼料を調製 し、これを投与した. 実験 II では新鮮油からTocを除 去し, 熱酸化油とToc レベルを同一にした後, 実験 I と同様に $20 \%$ 含油飼料を調製し投与した.

2.1 実験動物：実験 I, II とも 4 週令の COBS-Fisher 近交系雄ラットを購入し， 1 週間予備飼育した後, 体 重増加の順調なものを各群 8 匹ずつ用いた. ラットは, 一匹ずつヶージに入れ温度 $24 \pm 1^{\circ}$, 相対湿度 $50 \pm 5 \%$, 12 時間点灯で飼育した. 水および䬶は自由摂取させた。 体重は 3〜4 日毎に測定し，42 日後にと殺した。

2.2 投与飼料: 実験 I, II ともオリエンタル酵母(株) 製の精製飼料（B 配合）から脂肪分を除いたものを購入 し，これに含油量が $20 \%$ になるように各供試油を添加 乙調製した. 飼料の組成は, Table 2 に示すとおりであ る. 含油飼料は 1 週間毎に調製し, 密閉容器に入れて低
温室に保存した，週 2 回給慨を行い慨摄取量を測定後, 残慨は捨て給慨中の自動酸化の影響を避けた。 また 1 週 間ごとに供試油の POV を測定し自動酸化の影響のない ことを確認した。

なお，予備飼育に用いた固型飼料 (charls river, ラ ット用固型飼料）および実験 II で用いた各投与飼料に

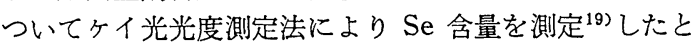
ころ, 固型飼料では, $0.43 \mathrm{ppm}$ 含有されていたのに対 し, 精製飼料 (FII, A，B，C を各 $20 \%$ 含有）では 0.021 0.025 ppm のレベルであった.

\section{3. 生化学的試験}

\section{1 試薬}

ラウリル硫酸ナトリウム (SDS)：和光純薬工業(株) 製, 生化学用

テトラエトキシプロパン: 東京化成工業(株)製，一級 品

5, 5'-ジチオビス (2-ニトロ安息香酸)，(DTNB)：半 井化学薬品(株) 製, $\mathrm{SH}$ 基定量用

フェノール試薬：和光純薬工業(株)製

牛血漿アルブミン: Armour 社製

$\mathrm{NADPH} \cdot 4 \mathrm{Na}$ : Sigma 社, type X

酸化型グルタチオン (GSSG): Sigma 社, Grade III 還元型グルタチオン (GSH): Sigma 社

グルタチオンレダクターゼ (GSSG-red): Sigma 社, type III

tert-ブチルハイドロパーオキサイド (tert-butyl$\mathrm{OOH})$ : 半井化学薬品(株)製

その他の試薬は市眅特級品を用いた。

\section{2 肝䀟ホモジネートおよび肝ミクロソーム分画, 肝 可溶性分画の調製}

投与実験開始後42日目のラットを軽いエーテル麻酔下 に断首し，放血後すみやかに肝蔵を取り出しロ紙により 
Table 4. Results of Experiment $I^{\mathrm{a})}$

\begin{tabular}{|c|c|c|c|c|}
\hline \multirow{2}{*}{ Parameters } & \multicolumn{4}{|c|}{ Group } \\
\hline & FI & A & B & $\mathrm{C}$ \\
\hline Weight gain $(g)$ & $132.3 \pm 23.2^{\mathrm{b})}$ & $134.0 \pm 11.9^{b)}$ & $135.6 \pm 6.7^{\mathrm{b})}$ & $137.5 \pm 10.2^{\mathrm{b})}$ \\
\hline Food intake (g) & $453.8 \pm 43.6$ & $473.0 \pm 21.0$ & $491.4 \pm 20.8^{*}$ & $496.3 \pm 27.1^{*}$ \\
\hline Food efficiency & $0.29 \pm 0.03$ & $0.28 \pm 0.02$ & $0.28 \pm 0.01$ & $0.28 \pm 0.02$ \\
\hline $\begin{array}{l}\text { Liver wt., g per } 100 \mathrm{~g} \text { body wt. } \\
\text { TBA-positive substance }\end{array}$ & $3.80 \pm 0.14$ & $4.06 \pm 0.13^{* *}$ & $4.39 \pm 0.09^{* *}$ & $4.32 \pm 0.15^{* *}$ \\
\hline Masugi's method ${ }^{(\mathbf{})}$ & $0.25 \pm 0.03$ & $0.50 \pm 0.10^{* *}$ & $0.63 \pm 0.05^{* *}$ & $0.82 \pm 0.13^{* *}$ \\
\hline Glutathione content ${ }^{\mathrm{d})}$ & $1.42 \pm 0.53$ & $2.35 \pm 0.63^{* *}$ & $2.79 \pm 0.37^{* *}$ & $2.83 \pm 0.71^{* *}$ \\
\hline Glutathione peroxidase activity ${ }^{\theta}$ & $5.77 \pm 1.62$ & $4.23 \pm 0.27^{* *}$ & $4.04 \pm 0.25^{* *}$ & $3.89 \pm 0.41^{* *}$ \\
\hline
\end{tabular}

a) Fresh rape seed oil (Tocopherol not removed, FI) was used for the control diet. The quality of fresh oil and thermally oxidized rape oils (A, B and C, obtained from manufacturers of fried fish paste), see Table 1. Rats were fed ad libitum for 42 days with diet which contained $20 \%$ sample oils.

b) Each value is the mean $\pm \mathrm{S}$. D. of 8 rats. ${ }^{\text {c) }}$ malonaldehyde, $\mu$ moles $/ \mathrm{g}$ liver

d) $\mu$ moles/g liver ${ }^{\text {e) }} \mu$ moles NADPH oxidized $/ g$ liver $/ \mathrm{min}$

* significantly different from FI group, $\mathrm{P}<0.05$

** significantly different from FI group, $\mathrm{P}<0.01$

血液をぬぐった後, 肝重量を測定する.肝臓 $3 \mathrm{~g}$ を精科 し, 直ちに氷冷した $75 \mathrm{~m} M$ リン酸カリウム緩衝液 $(\mathrm{pH}$ 7.0) $27 \mathrm{ml}$ を加光, アイスボックス中に保存する. ホモ ジネートおよび各分画の調製は Tsai ら ${ }^{20)}$ の方法に準 じ，と殺後の変化を避けるためできるだけ速やかに行っ た.

\subsection{TBA 陽性物質の測定法}

$10 \%$ 肝蔵ホモジネート $0.5 \mathrm{ml}$ を用いて行った. 実験

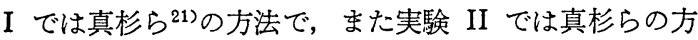
法と, 内山ら 22 の方法で行った.

\subsection{GSH 量の測定法}

Ellman ${ }^{23)}$ の方法を若干修正して行った．すなわち， $10 \%$ ホモジネート $2 \mathrm{ml}$ を, $10 \mathrm{ml}$ 容遠沈管に採りこれ に $8 \% \mathrm{TCA}$ 溶液 $2 \mathrm{ml}$ を加えよく振り混ぜた後, 3,000 $\mathrm{rpm}$ で 10 分間遠心分離する. 試験管に上澄液を $2 \mathrm{ml}$ 採取し， $0.4 M$ リン酸二ナトリウム溶液 $2.5 \mathrm{ml}$ を加え 振り混ぜた後，0.15\% DTNB（1\% クエン酸三ナトリウ ム溶液に溶かした子の） $0.5 \mathrm{ml}$ を加え振り混ぜて発色 させる. 2 分後に $410 \mathrm{~nm}$ に抢ける吸光度を測定する。

\subsection{GSH-px 活性の測定法}

Paglia ら ${ }^{24)}$ 执よび Little ら ${ }^{25)}$ の方法に準じて行っ た. GSH と tert-butyl-OOH の反応で生じた GSSG を, GSSG-red で還元する際消費される NADPH 量を， $340 \mathrm{~nm}$ に扩壮る吸光度の減少により求め, GSH-px の 活性を測定した. Table 3 に, assay system を示す.

\subsection{GSSG-red 活性の測定法}

Methods of Enzymatic Analysis ${ }^{26}$ に記載の方法に 準じて行った.

\section{7 肝ミクロゾームタンパク量, 肝可溶性 分画タン パク量の測定法}

Lowry ら 27)の方法により行った。

\section{実験結果}

\section{1. 実験 I の結果について}

Table 4 に実験 I の結果ををとめて示した。熱酸化油 投与群 (A，B，C 群) では, 対照群 (FI 群) に比較し て，体重増加量では有意差が見られなかった。餌の摂取 量は， B，C 群ではむしろ FI 群よりも多い傾向がみら れたが, 飼料効率 (体重増加量/䭒摂取量) では有意差が なかった。一方, 体重 $100 \mathrm{~g}$ あたりの肝重量は, A, B, C 群で有意に增大した。

肝蔵ホモジネートについて, TBA 陽性物質生成量を 真杉法を用いて測定したところ，FI 群に比し，A，B，C 群で供試油の劣化度に 対応して 有意に 增大した. 同じ く，ホモジネートについて，GSH 量を測定した結果， A, B, C 群で有意に増大した.

また，生体内で脂質過酸化物を分解する酵素である GSH-px 活性を， $100,000 \times \mathrm{g}$ 上澄液（肝可溶性分画） について測定したところ，A，B，C 群で有意に低下し た.

ところで, Toc には生体内での過酸化脂質生成を抑制 する作用のあることが知られているが, 実験 I では供試 油の Toc レベルに対する配慮はされていない。すなわ ち, 新鮮油では, Table 1 に示したとおり, $\alpha$-Toc $136.5 \mu \mathrm{g} / \mathrm{g}, \gamma$-Toc $504.5 \mu \mathrm{g} / \mathrm{g}$ および $\delta$.Toc $41.2 \mu \mathrm{g} /$ $\mathrm{g}$ を含有するのに対して，熱酸化油ではToc を全く含 有しない。上記の結果が Toc 含量の相違に起因するの 
Table 5. Results of Experiment $I^{a}{ }^{a}$

\begin{tabular}{|c|c|c|c|c|}
\hline \multirow{2}{*}{ Parameters } & \multicolumn{4}{|c|}{ Group } \\
\hline & FII & A & B & $\mathrm{C}$ \\
\hline Weight gain $(g)$ & $116.5 \pm 10.5^{\mathrm{b})}$ & $132.9 \pm 13.1^{\mathrm{b}) * *}$ & $125.8 \pm 11.7^{\mathrm{b})}$ & $129.6 \pm 16.7^{\mathrm{b}) *}$ \\
\hline Food intake $(g)$ & $421.5 \pm 31.8$ & $453.8 \pm 39.1$ & $451.6 \pm 33.2^{*}$ & $461.4 \pm 40.1^{*}$ \\
\hline $\begin{array}{l}\text { Liver wt., } \mathrm{g} \text { per } 100 \mathrm{~g} \text { body wt. } \\
\text { TBA-positive substance }\end{array}$ & $3.83 \pm 0.40$ & $4.03 \pm 0.14$ & $4.27 \pm 0.17^{*}$ & 4. $24 \pm 0.09 *$ \\
\hline Masugi's method ${ }^{\mathrm{c}}$ & $0.22 \pm 0.03$ & $0.43 \pm 0.13^{* *}$ & $0.48 \pm 0.08^{* *}$ & $0.60 \pm 0.07^{* *}$ \\
\hline Uchiyama's method ${ }^{(\mathbf{})}$ & $0.19 \pm 0.05$ & $0.39 \pm 0.14^{* *}$ & $0.36 \pm 0.06^{* *}$ & $0.52 \pm 0.08^{* *}$ \\
\hline Glutathione content $\mathrm{t}^{\mathrm{d})}$ & $3.21 \pm 0.44$ & $3.35 \pm 0.44$ & $3.77 \pm 0.51^{* *}$ & $3.92 \pm 0.56^{* *}$ \\
\hline Glutathione peroxidase activity $\left.{ }^{\theta}\right)$ & $5.73 \pm 1.17$ & $6.82 \pm 1.54$ & $5.57 \pm 0.51$ & $5.57 \pm 1.29$ \\
\hline Glutathione reductase activitye) & $6.42 \pm 0.57$ & $6.69 \pm 0.73$ & $7.25 \pm 0.48^{* *}$ & $6.88 \pm 0.30^{*}$ \\
\hline Microsomal protein $(\mathrm{mg} / \mathrm{g})$ & $19.3 \pm 1.5$ & $22.4 \pm 4.7$ & $28.7 \pm 1.9 * *$ & $29.8 \pm 3.2^{* *}$ \\
\hline Liver soluble protein $(\mathrm{mg} / \mathrm{g})$ & $93.9 \pm 6.3$ & $110.0 \pm 19.1^{*}$ & $93.5 \pm 7.1$ & $91.1 \pm 3.9$ \\
\hline
\end{tabular}

a) Tocopherol removed fresh rape seed oil (FII) was used for control diet. The quality of FII see

Table 1. Feeding conditions were equal to Experiment I. b) e) See Table 4

* significantly different from FII group, $\mathrm{P}<0.05$

** significantly different from FII group, $\mathrm{P}<0.01$

か，それ以外の要因によるのかを確認するため，次の実 験 II を実施した。

\section{2. 実験 II の結果について}

実験 II では, 新鮮油と熱酸化油の Toc レベルを同一 にすることを試みた。このためには，熱酸化油に各 Toc 同族体を添加し, 新鮮油と同一レベルにまで強化するこ とも考えたが, Toc 同族体の純品を多量に入手すること は現状では困難であることから，逆に新鮮油中の Toc を除去することを考光, 実験方法 1.2 で述べた方法で FII を調製し，これを対照とした。

Table 5 に実験 II の結果をまとめて示した. 体重増 加量, 餌摂取量は, FII 群よりむしろ A, B, C 群の方が 多い傾向を認めた. 体重 $100 \mathrm{~g}$ 当たりの肝重量は, $\mathrm{A}$, B， C 群で有意に増大していた。

TBA 陽性物質量は, 真杉法, 内山法ともに FII 群に 比し，A，B，C 群で供試油の劣化度に対応して有意に増 大した.

GSH 量は, B, C 群で有意に増大した.

GSH-px 活性は，有意差が見られなかったが，GSSGred 活性は, B, C 群で有意に上昇した.

また, ミクロゾーム分画タンパク量は, $\mathrm{A}, \mathrm{B}, \mathrm{C}$ 群で 有意に増大した。肝可溶性分画のタンパク量は, A 群が 若干高い値を示したが他は有意差がなかった。

考察

生体内脂質過酸化の測定法には, 共役ジェン測定法, ケイ光測定法, TBA 法等の in vitro の方法と, 呼気中の ペンタンまたはェタンの放出量から intact な生体での 脂質過酸化を測定する in vivo での方法 ${ }^{28)}$ とがある. こ のちち TBA 法は, 操作が簡便で感度も高く, 動物組織
での脂質過酸化湘定に広く用いられている方法である. 生体内過酸化脂質の成因には，生体膜が密接に関連し ており，その脂質二重層を形成するリン脂質は，多価不 飽和脂肪酸 (PUFA) に富み, 酸化的障害を受けて PUFA ラジカルを形成し, さらに酸素を吸収して過酸化 ラジカルや過酸化物に移行しやすい。この膜中に生成し た脂質過酸化物を，マロンアルデヒド前駆物質として TBA 反応で測定するためには，タンパク一脂質共存状 態でプロトン触媒下の加熱を必要とするが，真杉ら ${ }^{21)}$ 界面活性剂 (SDS) を用いて生体膜を可溶化する方法を 開発した，真杉らによると，ホモジネート中に最初から マロンアルデヒドとして存在する量は極めて少ないが, プロトン存在下での加熱で, intactな PUFA はほとん ど酸化分解されることなく、“きずついた”PUFAのみ がマロンアルデヒドに変化して測定されるとしている. また, 内山ら ${ }^{22)}$ も除タンパク剂としてトリクロル酢酸を 用いる従来法での問題点を検討した結果, 除タンパク剤 を用いず，リン酸で $\mathrm{pH} 2.0$ に調整して TBA 反応を行 わせ, $532 \mathrm{~nm}$ における吸光度から $520 \mathrm{~nm}$ における吸 光度を差しひいて測定する方法を開発した，TBA 反応 陽珄物質量の測定には, 従来法よりもこれら 2 法が信頼 しらると考えられる。

ラットの正常な飼育に必要な食慨中ビタミン E (Toc) 量は $15 \mathrm{ppm}$ といわれこれに基づいてけっ歯類の飼料 では通常 $40 \mathrm{ppm}$ 添加が推奖されている ${ }^{29)}$. 今回の実験

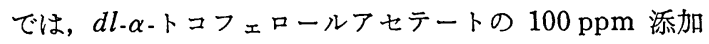
基礎飼料を用い，これに $20 \%$ 含油させているので，実験 I における FI 投与群を除き， A， B，Cおよび FII 投 与群での飼料中ビタミン $\mathrm{E}$ 含量は, いずれも $80 \mathrm{ppm}$ 
となる.ビタミン E は生体内での脂質過酸化の抑制作 用があり，したがって実験 II では特に新鮮油および熱 酸化油投与群での, 飼料中 Toc 含量の同一レベル化を 配慮したが，上記のとおり Toc レベルが必要量以上で あるにもかかわらず, 実験 I と同様, 実験 II において も, 熱酸化油投与群でその劣化度に対応して TBA 陽性 物質量が増大していることは, 熱酸化油中のなんらかの 酸化生成物が radical generator として作用し，ラット 肝藏の生体膜中に PUFA ラジカルの生成が増大した事 実を示している.

GSH は, 動植物細胞に広く分布しており細胞膜の保 護，パーオキサイドの分解，放射線照射により生じたフ リーラジカルの分解, また異物代謝に打いて GSH 抱合 体をつくり解毒することなど，数々の生物学的機能をも っているとされている.Wirth ${ }^{30)}$ らは正常な成熟ラット, 胎仔ラット, 腫瘍移植ラットに対して, ジェチルマレー ト (GSH と結合して, GSH 量を可逆的に減少させる物 質）を腹腔内投与して, 各ラット肝藏の GSH 量の変動 を調べている，それによると，正常ラットでは投与後 30 分で正常レベルの15\%にまで減少し，4 時間後から急速 に回復し 6 時間で正常値に，さらに24時間後には正常レ ベルの 2 倍にまで over shooting する. 担腫瘍ラット 肝，胎仔ラット肝ではこうした over shooting は見ら れなかったとしている，今回の，著者らの実験では，実 験 I, II とも熱酸化油投与群で GSH 量が有意に増大し たが，これは本実験に供したラットは，担腫瘍ラットや 胎仔ラットに比較すれば，むしろ正常ラットに近いと考 えられ, 熱酸化油含有飼料の自由摂取により, 生成した PUFA ラジカルが消費した GSH が, 再合成され over shooting した結果と推測される.

GSH-px 活性は, 実験 I では熱酸化油投与群で低下 したが，実験 II では有意差が見られなかった，投与飼 料の項でも触れたが，精製飼料中には Se 化合物が配合 されていないので, Se 含量は 0.021〜0.025 ppm の低 值であった. Hafeman ら ${ }^{31)}$ の実験によると, 飼料中の Se が $0.06 \mathrm{ppm}$ では，正常に成長はするが GSH-px に対する必要量には不足であり, Se を $0.1 \mathrm{ppm}$ レベル に添加することによって，GSH-px に対する必要量は 満たされるとしており，このことから今回の実験は, 低レベル Se 飼料での実験であったといえる。 また， GSH-px 活性を示す酵素には, Se 含有酵素 (Se-GSH$\mathrm{px})$ と $\mathrm{Se}$ 不含酵素の, 2 種が知られている. 後者は, GSH-S-transferase B であり, Se 欠乏時には, SeGSH-px が減少するのに対して, GSH-S-transferase B は増加するといわれている32). Se-GSH-px は, 過酸 化水素および有機ハイドロパーオキサイドの双方を基質 とするが, GSH-S-transferase B は, 有機ハイドロパ 一オキサイドのみを基質とする. 今回, 著者らは GSHpx の活性測定に, tert-Butyl-OOH を用いたが，この条
件では Se-GSH-px および GSH-S-transferase 双方の 活性の和を測定したことになる。したがって， Se の 必要量を配合した上で，同様な実験を行った場合に， GSH-px 活性がどのような挙動を示すか，興味が持た れるところである.

実験 II において，ミクロゾームタンパク量が，熱酸 化油投与群において増大している。これは, Andia ら $5^{332}$ が加熱油投与により肝ミクロゾーム酵素が誘導され，薬 物代謝活性が艺進し，比肝重量の増大をもたらすと述べ ていることと関連する可能性がある，しかしながら，真 杉ら ${ }^{21)}$ は in vivo で, 薬物代謝酵素活性の誘導と TBA 值があまり相関性を持たないと述べており, 結論は得ら れていない.

緒言でも触れたとおり，実験室的に極端な条件で熱酸 化させた油脂中では，有毒成分の生成も多く，さらにこ れをなんらかの方法で濃縮し，乙かも大量に投与した場 合に，実験動物に毒性が認められることはあっても，通 常の加熱条件では有毒成分の生成は微量であり，生体に 対する悪影響も認知し得ない, というのが大方の見解で ある、しかしながら，今回の著者らの実験の結果，揚物 調理に実際に使用されている油そのものによって，生体 内脂質過酸化が明らかに進するといら事実を確認した ことにより，フライ油が日常的に多用される必需食品で あることとあいまって，食品衛生上，あらためてその安 全性に対する見直しが必要ではないかと考える。また， TBA 陽性物質量と各化学指標との関係から, 特に ox. FA および $\mathrm{CoV}$ は，単に品質面のみでなく毒性面にお ける評価指標としても，有用ではないかと考えられる. そのためには，ox. FA 0.7\% 以下，または CoV 50 $\mathrm{meq} / \mathrm{kg}$ 以下の品質のフライ油などについても, 更に生 体内脂質過酸化に対する影響の程度を検討する余地を残 している.

浦上*2が，食用油脂の安全性について，放射線照射食 品との対比において指摘しているように，食用油脂の使 用は歴史的にはずいぶん古いが，その安全な使用法につ いての科学的な裏づけは, 現在に至るも未解決であり, フライ油の熱酸化で生じるそれぞれの有毒成分は微量で あっても，その種類は多く相乗作用，体組織への沈着な ぞが明らかになっていない，照射食品と油脂食品では， 歴史の長さは異なっても，いずれもフリーラジカル反応 といら点で共通しているので，熱酸化油の場合もさらに 検討する必要があろら。

\section{謝辞}

供試用フライ油の採取に御尽力いただいた京都市衛生 局環境衛生課, 保健所食品衛生監視員各位, および Toc 定量にあたり貴重な標品を提供していただいたェーザイ (株) 阿部皓一氏に厚く御礼申し上げます.

また，本研究にあたり御鞭撻を賜った当所，細川 汀 所長ならびに御協力いただいた山本行隆氏，吉川俊一氏 
に深く感謝いたします。

文献

1) 八木国夫：老年医学, 16, 1327 1431 (1978).

2) 原 一郎, 島崎弘幸: 化学と工業, 32, 151 153 (1979).

3）金田尚志：油化学， 29，295３00（1980).

4）内山 充, 佐藤政男：食衛誌。 11, 327 333 (1970).

5) Wantland, L.R., Perkins, E. G.: Lipids, 5, 191 200 (1970).

6) Nolen, G. A., Alexander. J.C., Artman, N. R.: J. Nutr. 93, 337 348 (1967).

7) Mankel, A.: Fette Seifen Anstrichm. 72, 483 487 (1970).

8) Poling, C.E., Eagle, E., Rice, E.E.: Lipids, 5, 128 136 (1970).

9) Waltking, A.E., Seery, W.E., Bleffert, G. W.: J. Am. Oil Chem. Soc. 52, 96 100 (1975).

10) Firestone, D., Horowitz, W., Friedman, L., Shue, G. M.: ibid., 38, 253 257 (1961).

11) Ohfuji, T., Kaneda, T.: Lipids $8,353 \sim 359$ (1973).

12) Kieckebusch, Jahr, K., Czok, G., Griem, W., Bässler, K. H., Hammer, D. C. H., Lang, K.: Fette Seifen Anstrichm. 64, 1154 1167 (1962).

13）井崎やえ子, 戸田和子, 藤原光雄：食衛誌. 18, 191 200 (1977).

14）井崎やえ子, 吉川俊一, 藤原 光雄：同上. 19, 474 481 (1978).

15) Mankel, A.: Fette Seifen Anstrichm. 76, 20 $\sim 25$ (1974).

16) 梶本五郎, 吉田 弘美, 芝原 章: 油化学, 24, $511 \sim 517$ (1975).

17) Urakami, C., Doi, H., Toriyama, S: 同上, 25, 764 772 (1976).
18）阿部皓一，涌口泰昌，勝井五一郎：栄羕と食糧, 27, 329 334 (1974).

19）日本薬学会編：“衛生試験法注解” p. 56 57; p. 423４24（1980）金原出版.

20) Tsai, A.C., Thie, G. M., Lin, C.R.-s.: J. Nutr. 107, 310〜319 (1977).

21）真杉文紀， 中村哲也：ビタミン， 51， 21〜29 (1977).

22) Uchiyama, M., Mihara, M.: Analytical Biochemistry, 86, 271 278 (1978).

23) Ellmann, G. L.: Arch. Biochem. Biophys. 82, $70 \sim 77$ (1959).

24) Paglia, D. E., Valentine, W. N.: J. Lab. \& Clin. Med. 70, 158 169 (1967).

25) Little, C., Olinescu, R., Reid, K. G., O’Brien, P. J.: J. Biol. Chem. 245, 3632 3636 (1970).

26) Bergmeyer, H.U.: "Methods of Enzymatic Analysis" 2 nd English edition p. 465 466 (1974) Academic Press. Inc. New York.

27) Lowry, O. H., Rosebraugh, N. J., Farr, A. L., Randall, R. J.: J. Biol. Chem. 193, 265 275 (1951).

28）嶬峨井 勝, Tappel, A. L.: 医学のあゆみ, 106, 681 683 (1978).

29) Trostler, N., Brady, P.S., Romsos, D. R., Leveille, G. A.: J. Nutr. 109, 345 352 (1979).

30) Wirth, P.J., Thorgeirsson, S.S.: Cancer Res. 38, 2861 2865 (1978).

31) Hafeman, D. G., Sunde, R. A., Hoekstra, W. G.: J. Nutr. 104, 580 587 (1974).

32) Lawrence, R. A., Parkhill, L. K., Burk, R. F.: ibid., 108, 981 987 (1978).

33) Andia, A. M. G., Street, J. C.: J. Agr. Food Chem. 23, 173 177 (1975). 